\title{
Development of Module Teaching Materials Writing Short Texts of Literacy-Based for Students of Senior High School Parulian 1, Medan, Indonesia
}

\author{
Kasman Supriadi ${ }^{1}$, Khairil Ansari ${ }^{2}$, Abdurahman Adisaputera ${ }^{2}$ \\ ${ }^{l}$ Master Student in State University of Medan (Unimed), Medan, Indonesia \\ ${ }^{2}$ Lecturer in State University of Medan (Unimed), Medan, Indonesia \\ kasmansupriadi7@gmail.com
}

\begin{abstract}
The aims of this study is to find out the development of module teaching material of writing short story of literacy based in Senior High School Parulian 1 medan. The research method of this study is qualitative research. The result show that The development of module teaching materials is carried out by determining the title, objectives, material selection, framework preparation, and collection of relevant materials with short story writing material and the techniques used in writing short stories. In addition, to assess the feasibility of the product being developed, validation tests were conducted involving expert lecturers, and Indonesian language teachers, as well as limited student testing. Feasibility assessment of this module includes 4 aspects, namely aspects of content / material, presentation, language, and graphics.
\end{abstract}

Keywords : development; teaching material; writing short text; Parulian school

\section{Introduction}

Teaching materials in the form of modules are a complete set of learning activities. This is clearly seen in the presentation of Sanjaya, 2008: 331 that the module is a complete unit that stands alone from a series of learning to help students achieve a number of objectives specifically and clearly formulated, starting from learning objectives, learning instructions or a series of learning activities that must be done students, learning materials, until evaluation along with guidelines determine their success so that with modules students can learn independently. In addition, the module is a way of organizing subject matter that takes into account the function of education. More clearly Syamsudin 2005: 168 reveals that modules are printed teaching materials designed to be studied independently by learners.

Modules also make students more interested in learning which can automatically improve learning outcomes (Herawati, 2013: 80). Learning systems with module facilities have been developed both inside and outside the country known as the Modular Learning System (SBB). SBB has been developed in various forms such as Individualized, study system, self-passed study course, and peer test (Tjipto Utomo and Kees Ruijter, 1990). Even though the module found by researchers in schools is an old module that is not relevant to the current demands of the government, namely literacy-based learning, even the modules contained in schools are not obtained by all students. And after the researcher conducted the interview, it was evident that the module received by students did not motivate students in independent learning. Based on the results of the interview, it was evident that the old module did not have a series of interesting learning activities, too wordy material and the module was dull (module attached).

Development of old modules is a solution chosen by researchers to solve the problems mentioned above because modules are teaching materials designed to be studied independently by learner participants (Purwanto et al., 2008). They are said to be independent because they have been equipped with self-learning indicators without the presence of the teacher directly. Language, patterns, and other completeness attitudes contained in the module are designed with "teaching language" so that it is as if the teacher is teaching. 
The product specifications expected in this study are module-based literacy as the literacy movement is currently highly appreciated and is being promoted by the government in the world of education. Based on the regulation of the minister of education and culture number 23 of 2015, the minister of education and culture of the Indonesian republic issued an education program called the School Literacy Movement (GLS). The program has a low background in literacy skills that prove the educational process has not developed the competence and interest of students in knowledge. Sutriadnto et al., 2016 explained that reading literacy tests measure aspects of understanding, using, and reflecting reading results in the form of writing in the 2011 international reading literacy study (PIRLS). Literacy is also very much related to learning Indonesian in schools, namely to foster and develop students' self-confidence as think-tank communicators (including imaginative thinkers) and become literate and informed citizens. Added 2013 curriculum which generally aims to enable students to be able to listen to reading and viewing (viewing), speaking and writing.

According to the director general of secondary education (2016: 5), literacy is more than just reading and writing, but also includes thinking skills using sources of knowledge in print, visual, digital, and auditory so that this ability is called information literacy . Burhanuddin, http: //www.kompasiana.com states that reading and menu skills are very important to have because both of these abilities can open and provide insight into thinking, stimulate imagination, create creativity, guide critically and objectively with various perspectives to make the mind more reflective so not monotonous and stagnant. More Palani (2012) reading habit is an essential and important aspec for creating a literate society in the word.

\subsection{Module}

\section{Review of Literature}

Modules can be interpreted as subject matter that is compiled and presented in writing in such a way that the reader is expected to absorb the material themselves. In other words the module is a learning material where the reader can learn independently.

According to Majid (2011: 176) explained that "Modules are a book written with the aim that students can learn independently without teacher guidance, so that the module contains at least all the basic components of teaching materials." A module will be meaningful if students can easily use it.

Furthermore, the understanding of modules according to Ashyar (2012: 155) can be defined as one form of mold-based teaching material that will be designed to study independently by learner participants, therefore the module is equipped with instructions for self-study. Students can carry out their own learning activities without the presence of the teacher directly. Depdiknas (2008: 20) defines that Modules are a set of teaching materials that are presented systematically so that users can learn with or without a teacher. Thus a module must be used as a teaching material in lieu of the teacher's function.

Trianto (2011: 227) explains that "the module is a guidebook for students in learning activities that includes subject matter, investigation activities based on concepts, scientific activities, information, and examples of the application of science in everyday life." Learning with modules allows a student who has a high speed in learning will more quickly complete one or more basic competencies compared to other students. 


\subsection{Definition of writing}

Writing is an activity carried out by someone to produce a writing (Badriyah et al. 2007: 614). Furthermore, Dalman (2012: 5) states that writing is a process of relating words, sentences, paragraphs, and between chapters logically so that they can be understood. There are two writing activities that can be done, namely learning to write and writing to learn (Brewster and Ellis, 2002: 117)

Writing can also be said as an activity of arranging letters into words or sentences to be conveyed to others, so that others can understand them. In this case, communication between the writer and the reader can occur well. Writing is the result of one's activities placing something in a dimension of space that is still empty (Resmini et all. 2006: 287). While in Oxford Dictionary, "writing is producing something in written form so that people can read, perform or use it.". Mulyono, 1999: 224 says writing is a visual depiction of thoughts, feelings or ideas, using symbols of the system of language researchers for the purposes of communication or taking notes. (http://digilib.unnes.ac.id/gsdl/collect/skripsi/archives/HASH6160.dir/doc.pdf, 17 Desember 2010).

Orr (Growing up with english, 1999: 79) argues that there are 5 stages in the writing process, namely: prewriting, drafting, sharing, revising and publishing. Whereas according to Tarigan (2008: 3) writing is a productive and expressive activity. Agreeing with Tarigan, Iskandarwassid and Sunendar (2008: 248) suggest that like speaking ability, writing relies on language skills that are active and productive. Both of these skills are attempts to express feelings and thoughts that exist in a language user through language. "Just as you may not know what you're going to say until you say it, so you may not know what you are going to write until you write it" (Carol Cox, 1999: 309).

\subsection{Defenition of Literacy}

Literacy which in English is literacy comes from Latin littera (letters) whose understanding involves mastery of writing systems and accompanying conventions. Literacy is the quality or ability of literacy / literacy which includes the ability to read and write. Moreover, the meaning of literacy also includes visual literacy, which means the ability to recognize and understand the ideas conveyed in a visual way. However, literacy is primarily related to language and how the language is used. As for the written language system, it is almost universal. When talking about language, it certainly cannot be separated from the talk of culture because language itself is part of culture. Thus, the definition of the term literacy must certainly include the element that encompasses the language itself, namely its social cultural situation.

From the statement above, it can be seen that literacy requires complex capabilities. Knowledge about genres is knowledge about the types of genres that apply in discourse communities, for example, narrative texts, expositions, descriptions, and so on.

According to Richard Kern $(2000,16-17)$ the definition of literacy forms the principle of literacy education, namely:

1. Interpretation: the writer and the reader participate in the interpretation, namely the writer interprets the world (events, experiences, ideas, feelings, ideas, etc.), and the reader then interprets the author's interpretation in his own form of conception of the world.

2. Collaboration: there is cooperation between two parties namely the writer and the reader. The intended cooperation is in an effort to achieve a common understanding. 
The author decides what must be written or which does not have to be written based on their understanding of the reader. Whereas readers devote their motivation, knowledge, and experience to interpret the author's text.

3. Convention: this convention includes rules of language both oral and written. Someone reading and writing or listening and speaking is determined by cultural conventions / agreements (not universal) that develop through use and are modified for individual purposes.

4. Cultural knowledge: reading and writing or listening and speaking function in systems of attitudes, beliefs, habits, ideals, and certain values. For this reason, literacy involves cultural knowledge.

5. Problem solving: words are always attached to the linguistic context and the surrounding situation, so not reading, writing, listening, and speaking involves trying to imagine the relationships between words, phrases, sentences, units- units of meaning, texts, and the world. This attempt to imagine is a form of problem solving.

6. Reflection and self-reflection: writers and readers think of language and its relationships with the world and oneself. After being in a communication situation they think about what they have said, how to say it, and why say it.

7. The use of language: literacy is not a limit on language systems (writing/writing) but rather requires knowledge of a language to be used in both oral and written contexts to create a wreath.

\section{Research Method}

The research was conducted at senior high school Parulian 1 Medan in August 2018. The population of research and development was the grade XI students of senior high school Parulian 1 Medan. To see the effectiveness of the products developed, researchers only take samples using random sampling techniques, or random samples, or mixed samples. The researcher took a sample of 34 students.

\section{Discussion}

After the stages of gathering information obtained through the study of Indonesian language textbooks, questionnaires, and interviews completed and the data already analyzed, the next step is the preparation of module teaching materials. The first step in designing module teaching materials is to determine the title, namely "Learning Module Writing Short Story Text Literacy-Based for Senior High School / MA XI Grade Students". After the title of the module teaching material has been established, the next step is the determination of objectives, material selection, framework preparation, and material collection. The following is an explanation of the stages.

\subsection{Determination of Goals}

The objectives referred to in this case are learning objectives in each basic competency. The purpose is to describe what is expected and mastered by students after learning with the module's teaching materials. The general purpose of learning using this module teaching materials is that students are able to write short story based literacy texts, while the specific objectives, namely 1) students are able to understand the meaning of short stories along with 
the structure and rules of a good short text, 2) students are able to write coherent short stories according characteristics of the text to be created.

\subsection{Material Selection}

At this stage the selection of materials will be included in the module teaching materials, including: selection of theories, topics, concepts, reading texts, and pictures / illustrations that are in accordance with KD. The choice of material must be in accordance with the characteristics of students, for example using language that is easily understood by students, the reading text is not too long and in accordance with the theme of high school students, and the use of images that are appropriate to the topic.

\subsection{Framework Arrangement}

Arranged in accordance with the reference and consideration of the results of the analysis of the needs of students and teachers. Although in the preparation of learning material writing short story texts developed there are many adjustments with several considerations, but the results of questionnaire analysis of fixed needs serve as a reference in the preparation of learning material to write short story texts developed and adapted to the needs of students and teachers in Senior High School of Parulian 1, Medan.

The color of the cover used in the learning material is writing literacy based short stories, namely chocolate, green and orange. The colors are combined with blue so that the image used on the cover is a picture of the book tree on the front of the cover. Meanwhile, the writings contained in the cover include the title, class, name of the researcher, and the name of the supervisor. The more widely used font is Times New Roman. Color and image arrangement, as well as writing are placed in the appropriate position and look attractive. To be more clear can be seen in figure 4.1 below.

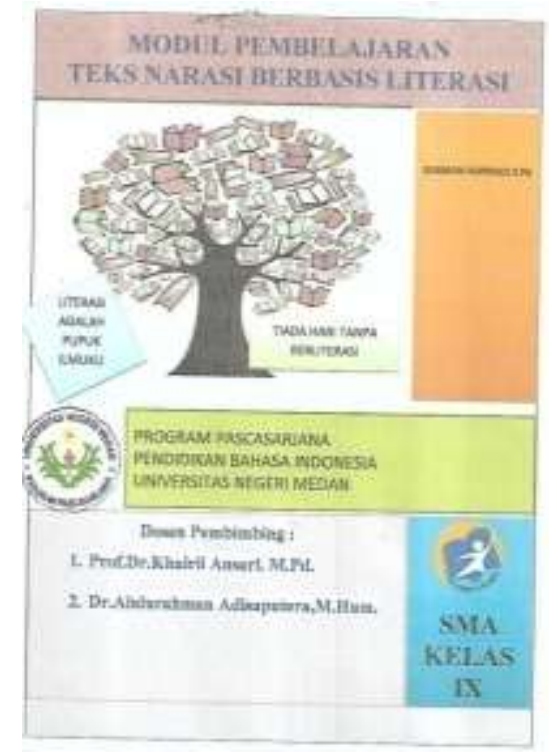

Figure 1 Cover Module Short Text Learning Materials

The physical form of developing learning material writes literacy-based short stories in the form of modules. The learning material module writes literacy-based short stories containing short story texts, examples, exercises, and evaluation questions. The material is 
presented in three activities that must be completed by students. Short story text modules can manage students' messages and responses so that the module can interact with students and be reciprocal. Short story text module packed with A4 size (176 x $250 \mathrm{~mm})$.

The display shown from the beginning to the end of the module uses bright colors that do not damage or disrupt the display and provide comfort for students. The font used in the overall appearance is Time New Roman and Christian ITC. For more details, the module display in general can be seen in Figure 4.2.
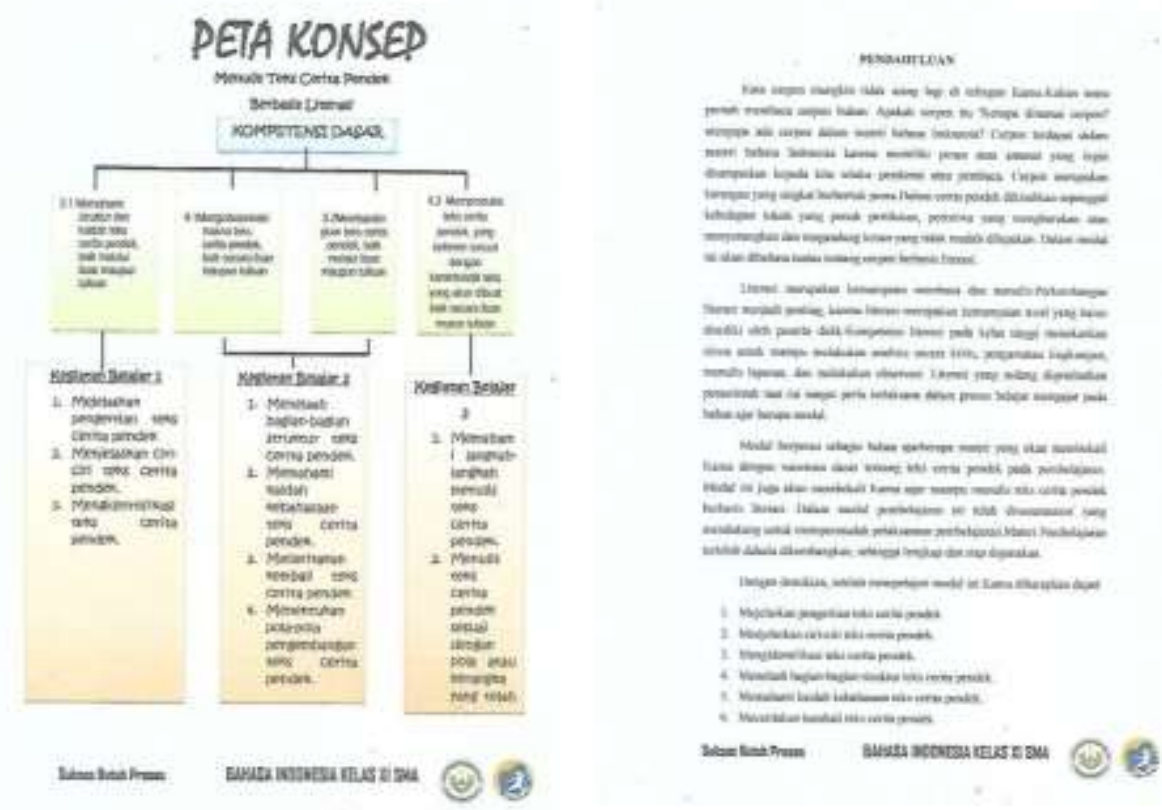

Figure 2. Module View

The development of literacy-based learning material for XI Grade of Senior High School Parulian 1 Medan contains short story text material. The material presented in the module is tailored to the needs of students and teachers. The material presented was obtained from several book references and the internet. The short story text module is also equipped with examples, exercises, and evaluation questions. The contents of the short story text module are divided into three activities, namely activities one, two and three with literacy based. The following is an explanation of each activity in the module. (1) This first activity contains one basic competency consisting of three indicators and learning objectives. The first activity has examples and writing exercises as the final task of literacy basis. (2) The second activity contains two basic competencies consisting of four indicators and learning objectives. This second activity has examples and writing exercises as the final task of literacy bases. (3) The third activity includes an indicator consisting of three indicators and learning objectives. This third activity also has examples of text and writing as the final task of literacy.

The material presented in the first activity is about the understanding of short story texts, the characteristics of short story texts, and the classification of short story texts. The material presented in the second activity is about the parts of the structure of the short story text, the language rules of the short story text, the general idea of short story texts, summarizing the short story text. The material presented in the third activity is about determining the patterns of developing short stories, the steps to write short stories, writing short stories according to the 
pattern or framework that has been designed. In addition to material exposure, the module includes examples of its application to clarify the material that has been delivered. An example of the application presented is about the short story text. The example is adjusted to the basic competencies of writing short story texts that must be mastered by senior high school students.

Module development of learning material writing literacy based short story texts containing evaluation questions. The evaluation questions amounted to fifteen items in the form of multiple choices. The questions presented are adjusted to the material that has been submitted to the content of the material. Therefore, students must learn the material well presented so that they can answer all questions.

The data obtained in this study are of two kinds, namely quantitative data and qualitative data. Validation of literacy based short story text material was carried out by expert lecturers held in January 2019. Validation data for literacy based short story text material was obtained from the results of evaluations carried out by material validator / lecturer and design expert validator / lecturer. The assessment of module design for developing learning material for writing literacy-based short stories for senior high school grade XI was conducted after the short story text module was completed and ready to be assessed, while the improvement of short story text modules was conducted after the short story text module was assessed by experts. The aspects assessed by expert validators / lecturers both material and design can be seen in table 4.7 below.

Table 1 Aspects Validated by Expert Lecturers

\begin{tabular}{|c|c|}
\hline Validation aspect & Validation Process \\
\hline $\begin{array}{l}\text { 1) 1) Aspects of Feasibility of Material } \\
\text { 2) 2) Aspects of Language Feasibility } \\
\text { 3) 3) Aspects of Feasibility of } \\
\text { Presentation } \\
\text { 4) 4) Material Effect Aspects of } \\
\text { Learning } \\
\text { 5) Comprehensive Display Aspects }\end{array}$ & Validated by material experts \\
\hline 1) Integrity Aspect & Validated by design experts \\
\hline
\end{tabular}

Validation of content or material to the product learning material writes short text from several aspects of material feasibility, aspects of language feasibility, aspects of feasibility of presentation, aspects of material effects on learning, aspects of overall appearance, and graphic aspects. This validation was carried out by Prof. Amrin Saragih, M.A., Ph.D., and Dr. Surya Masniari Hutagalung, M.Pd., as a material expert. Prof. Dr. Efendi Napitupulu, M.Pd., and Prof.Dr. Efi, M.Pd., as a design expert. Validation was carried out to get an assessment, improvement, and suggestions for learning material developed to improve the quality of learning in grade XI senior high school Parulian 1 Medan on literacy based short story text material.

The data obtained is quantitative data and qualitative data. Quantitative data comes from assessment questionnaires with a scale, while qualitative data in the form of additional assessment or suggestion validator. The results of the validation were analyzed to determine the feasibility or non-feasibility of the learning material developed in the form of modules in literacy-based short story text learning material to be used in grade XI senior high school Parulian 1 Medan. 
Assessment of short story text modules is carried out by two material experts. The criteria for material experts / content are lecturers with S-3 criteria for education / noneducation, not a thesis supervisor. The results of the assessment will determine the criteria for the learning material developed. Validated aspects are aspects of material feasibility, aspects of language feasibility, aspects of feasibility of presentation, aspects of material effects on learning, and overall aspects of appearance. This validation was carried out by Prof. Amrin Saragih, M.A., Ph.D., and Dr. Surya Masniari Hutagalung, M.Pd.

Product development in the form of short story text learning materials based on grade XI senior high school Parulian 1 Medan. The following is quantitative data from the results of the validation of the material / content aspects developed.

Table 2. Results of Assessment of Feasibility Aspects of Module Materials

\begin{tabular}{|l|l|l|}
\hline No. & Indicator & Score \\
\hline 1. & $\begin{array}{l}\text { Suitability of the content of learning material with Basic } \\
\text { Competence (KD) and learning objectives }\end{array}$ & 100 \\
\hline 2. & $\begin{array}{l}\text { The truth of the material concept is reviewed from the } \\
\text { scientific aspect }\end{array}$ & 100 \\
\hline 3. & Clarity of learning topics & 100 \\
\hline 4. & Material disorder & 90 \\
\hline 5. & Material coverage & 90 \\
\hline 6. & Material completeness & 90 \\
\hline 7. & $\begin{array}{l}\text { Conformity of the level of difficulty and abstractness of the } \\
\text { concept with the cognitive development of senior high school } \\
\text { students of grade XI }\end{array}$ & 90 \\
\hline 8. & $\begin{array}{l}\text { Linkage of material samples to conditions in the surrounding } \\
\text { environment }\end{array}$ & 90 \\
\hline 9. & Clarity of examples given & 90 \\
\hline 10. & $\begin{array}{l}\text { The accuracy of the material and examples to develop } \\
\text { learning independence }\end{array}$ & 90 \\
\hline 11. & Conformity evaluation with material and learning objectives & 90 \\
\hline 12. & The truth of the answer key is presented & 90 \\
\hline 13. & The accuracy of short story texts with material & 90 \\
\hline 14. & $\begin{array}{l}\text { The content of cognitive, psychomotor and affective aspects } \\
\text { of the material presented }\end{array}$ & 90 \\
\hline Total & 1290 \\
\hline Maximum score & 1400 \\
\hline Percentage & $89,84 \%$. \\
\hline & \multicolumn{1}{|c|}{. } & 90 \\
\hline
\end{tabular}


Based on table 4.10 the percentage of the material aspect / content of the module is $89.84 \%$. in the "valid" category. Thus, it can be concluded that the learning material developed in the feasibility aspect of the module material has met the eligibility criteria of the teaching material. This can be seen from each value obtained.

Product development in the form of short story text learning materials based on grade XI senior high school Parulian 1 Medan.

Table 3. Results of Assessment of Aspects of Module Language Feasibility

\begin{tabular}{|l|l|l|}
\hline No. & Indicator & Score \\
\hline 1. & Clarity of instructions for using learning materials & 90 \\
\hline 2. & Accuracy of terms & 90 \\
\hline 3. & $\begin{array}{l}\text { Ease of understanding the flow of material through the use of } \\
\text { language }\end{array}$ & 90 \\
\hline 4. & Politeness of language use & 90 \\
\hline Total & 360 \\
\hline Maximum Score & 400 \\
\hline Percentage & $90 \%$ \\
\hline
\end{tabular}

Based on the table above the percentage of the feasibility aspect of the module language is $90 \%$ in the "valid" category. Thus, it can be concluded that the learning material developed in the aspect of module language feasibility has met the eligibility criteria of teaching materials. This can be seen from each value obtained.

Product development in the form of short story text learning materials based on grade XI senior high school Parulian 1 Medan. The following are quantitative data from the results of the validation of the feasibility aspects of the presentation of the modules developed can be seen in table 4 below.

Table 4. Results of Assessment of Feasibility Aspects of Module Presentation

\begin{tabular}{|l|l|l|}
\hline No. & Indicator & Score \\
\hline 1. & Support for learning materials on student & \\
\hline 2. & Image presentation & 100 \\
\hline 3. & Complete presentation & 100 \\
\hline \multicolumn{2}{|l|}{ Total } & 100 \\
\hline \multicolumn{2}{|l|}{ Maximum Score } & 300 \\
\hline \multicolumn{2}{|l|}{ Percentage } & 300 \\
\hline
\end{tabular}

Based on the table above the percentage in the feasibility aspect of presenting the module is $100 \%$ with the category "valid". Thus, it can be concluded that the learning material developed in the feasibility aspect of module presentation has met the eligibility criteria of teaching materials. This can be seen from each value obtained.

Product development in the form of short story text learning materials based on grade XI Senior High School Parulian 1 Medan. The following is quantitative data from the results of 
the validation of the feasibility aspects of the module material on the learning developed which can be seen in the following table 5 .

Table 5. Results of Assessment of Aspects of Material Effects on Modules

\begin{tabular}{|l|l|l|}
\hline No. & Indicator & Score \\
\hline 1. & Ease of use. & 90 \\
\hline 2. & $\begin{array}{l}\text { Support for learning materials for student learning } \\
\text { independence. }\end{array}$ & 90 \\
\hline 3. & $\begin{array}{l}\text { The ability of learning materials to increase student } \\
\text { motivation in learning Indonesian. }\end{array}$ & 90 \\
\hline 4. & The ability of learning material adds knowledge. & 90 \\
\hline 5. & The ability of learning material broadens students' horizons. & 90 \\
\hline Total & 450 \\
\hline Maximum Score & 500 \\
\hline Percentage & $90 \%$ \\
\hline
\end{tabular}

Based on the table above the percentage of the effect aspects of the module material on learning is $90 \%$ in the "valid" category. Thus, it can be concluded that the learning material developed in the feasibility aspects of the module's effect on learning has met the eligibility criteria of teaching materials. This can be seen from each value obtained.

Product development in the form of short story text learning materials based on grade XI Senior high school Parulian 1 Medan. The overall appearance of the module developed can be seen in table 6 . below.

Table 6 Results of Assessment of Aspects of Comprehensive Module Display

\begin{tabular}{|l|l|l|}
\hline No. & Indicator & Score \\
\hline 1. & Attractiveness of book cover & \\
\hline 2. & Ease in reading text / writing. & 90 \\
\hline Total & 100 \\
\hline \multicolumn{2}{|l|}{ Total Score } & 190 \\
\hline \multicolumn{2}{|l|}{ Maximum Score } & 200 \\
\hline
\end{tabular}

Based on the table above the percentage of the overall display aspect of the module on learning is $95 \%$ with the category "valid". Thus, it can be concluded that the learning material developed in the feasibility aspect of the overall display of modules has met the eligibility criteria of teaching materials. This can be seen from each value obtained.

Research and development was carried out with the aim of producing a product in the form of a literacy text learning module based on grade XI Senior High School Parulian 1 Medan while testing the effectiveness of the product so that it could be used by grade XI students of Senior High School Parulian 1 Medan. Therefore, the process of research and development is carried out and begins with several stages, including (1) Conducting preliminary studies through observation and literature. From the results of observations obtained data that students 
really need teaching materials. (2) Designing products to produce the initial product of short story text learning material. (3) Develop short story text learning material. This activity includes introductory words, KI and KD, learning activities, and bibliography (4) The design of learning activities includes learning material, summaries, tests, and answer keys. (5) Conduct validation and revision, this activity includes product evaluation to find out the strengths and weaknesses of the quality of content and design carried out by material experts and design experts. The evaluation results will be used as material for product revisions. (6) Conducting individual trials, small group trials, and limited field trials so that it is produced in the form of a literacy text based short story text module in grade XI Senior High School Parulian 1 Medan that is suitable for use. Furthermore, to test the effectiveness of the product being developed, students are given a writing test to measure the understanding and skills of each student before and after the explored text learning material that is developed is applied in the learning process.

The results of the validation of learning materials by material experts and design will be described first. The results of the validation provided by the material experts on the developed teaching materials obtained content eligibility of $92.14 \%$ with the category "valid", the feasibility of presentation of $100 \%$ with the category "valid", and language feasibility of $90 \%$ with the category "valid". The results of the average percentage on the overall display aspect of the module on learning are $95 \%$ in the "valid" category. Furthermore, the results of validation by design experts on the graphic aspects of the module are $90.77 \%$ with the category "valid". Based on the description of the material feasibility and the design of the instructional materials developed, it can be concluded that the module of literacy text-based short story learning material in grade XI of Senior High School PARULIAN 1 MEDAN has fulfilled the requirements and applicable provisions with reference to the standards of assessment of the learning material set. In other words, the learning material developed has been feasible to be tested in the field.

\section{Conclusion}

Based on the results of the research and discussion on product development in the form of a module entitled Writing Literacy-Based Short Text for Senior High School / MA grade XI Students, the following conclusions are obtained.

First, Indonesian language textbooks used in learning are useful to make it easier for teachers to provide the material taught. Besides textbooks can be used for group learning, they can also be used to study independently. In addition, Indonesian language textbooks can also improve students 'ability in writing short stories because they are equipped with literary works that can improve students' short story writing skills. However, students are less interested in learning to write short stories. Besides being a factor in teaching monotonous Indonesian language teachers, the supporting facilities to attract students' interest in writing short stories are still minimal. Students only use one reference book as a source of learning, so does the teacher. Even though the teacher has another source book, the material is not in accordance with the main book which is an Indonesian textbook published by the Ministry of Education and Culture. The book, even though it uses communicative language, there are still conceptual errors in it, besides the selection of material that is not in accordance with the level of student competence, and also the use of scientific terms that make it difficult for students to understand the material. 
Second, the Literacy-based short story text writing module was developed through five stages of development. The five stages include research and information gathering, product development, validation tests, product revisions, and product trials.

The development of module teaching materials is carried out by determining the title, objectives, material selection, framework preparation, and collection of relevant materials with short story writing material and the techniques used in writing short stories. In addition, to assess the feasibility of the product being developed, validation tests were conducted involving expert lecturers, and Indonesian language teachers, as well as limited student testing. Feasibility assessment of this module includes 4 aspects, namely aspects of content / material, presentation, language, and graphics.

Third, the learning module for writing short story based on literacy text on the content / material aspect obtained an average score of 4.16 with the category "good", the presentation aspect obtained an average score of 4.24 with the category "very good", aspects of language gained the average score is 4.08 with the category "good", and the graphic aspect gets an average score of 4.36 with the category "very good".

If the four scores of the four aspects are accumulated, Literacy-based short story text module teaching materials obtain an average score of 4.21 with a percentage of eligibility of $84.2 \%$. From the results of the assessment it can be concluded that the module entitled LiteracyBased Short Text for Senior High School / MA grade XI Students is declared very feasible to use.

\section{References}

Suparno and MohamadYunus. 2008. Keterampilan Dasar Menulis. Jakarta: Universitas Terbuka

Tarigan, H.G. 2008.Menulis Sebagai Suatu Keterampilan Berbahasa.Bandung:Angkasa

Slamet, St.Y. 2007. Dasar-Dasar Keterampilan Berbahasa Indonesia. Surakarta:Universitas Sebelas Maret Press

H. R. Tarigan, Menulis Sebagai Suatu Keterampilan Berbahasa,Bandung: Angkala, 1986

Hullon Wills, Stucture, Style, and Usage a Guide to Expository Writing. California: Holt, Rinehart and Winston, 1966.

A.S Hornby, Oxford Advanced Learner's Dictionary of Current English.London: University Press, 1995

Harry A. Greene and friends Developing Language Skills in the Elementary School.Boston, London, Sydney

Hobri. 2010. Metodologi Penelitian Pengembangan (Aplikasi Pada Penelitian PendidikanMatematika). Jember: Pena Salsabila..

Prastowo, A. 2011.Panduan Kreatif MembuatBahan Ajar Inovatif.Jogjakarta:

DIVA Press.

Sanjaya, W. 2008. Strategi Pembelajaran Berorientasi Standar Proses Pendidikan.Jakarta: Kencana Prenada Media Group.

Sugiyono. 2011. Metode Penelitian Kuantitatif Kualitatif dan R\&D. Bandung:Alfabeta.

Yunita, I. 2011. Pengembangan Modul Pembelajaran SPLDV Beracuan Pada Standar Proses sebagai Alternatif Pembelajaran Matematika untuk Siswa SMP/MTs Kelas VIII. Skripsi tidak diterbitkan. Malang:Universitas Negeri Malang. 